\title{
FOLK ART AND NATIONALISM IN THE 20TH CENTURY INDIA
}

\section{RITESH RANJAN}

Chitkara School of Art \& Design, Chitkara University, Punjab, India

\begin{abstract}
The issue with admiring the static idea of society workmanship is that it shields the craftsmen from improving their lives, at the danger of forsaking their work to search out other financial chances. Through the authentic case of the people painters of West Bengal, called patuas, this paper plans to show how the safeguarding of society workmanship relies upon finding some kind of harmony between adjusting to stay applicable and hence monetarily practical to a given culture, and protecting an association with its chronicled roots. By clarifying how patua painting, likewise called patachitra, has explored the social movements of the most recent two centuries and endure, I would like to show the convoluted relationship India has with its own masterful history, and how people craftsmen can keep on making their employment off of their customary specialty. Patachitra, in its numerous structures, demonstrates that the best trust in people workmanship is conservation through adjustment.
\end{abstract}

KEYWORDS: Indian Art, Folk Art, Nationalism in Art, Indian Folk Art, Modernism, Patachitra \& Kalighat Painting

Received: May 07, 2020; Accepted: May 27, 2020; Published: Jun 30, 2020; Paper Id.: IJMPERDJUN2020258

\section{INTRODUCTION}

To comprehend the problem of continuing patachitra that is being considered in the 21 st century, it is first important to comprehend why other people expressions, rather than patachitra, flourished in the twentieth century. Kalighat compositions demonstrated that with the best possible crowd, patuas could adjust their work to new settings. In any case, patachitra was not the sort of craftsmanship that legislators and high society educated people were searching for in the mid twentieth century. So far, other than Kalighat taps, country patuas were in the propensity for voyaging and introducing their work, not selling it. Accordingly inside oneself continuing economy that was principal to the Swadeshi development, there was no spot for patuas. Be that as it may, the manner by which the scholarly first class advertised different painstaking work to the open set up a model for the 21 st century make showcase. Meanwhile patachitra slipped once again into country indefinite quality among the overall population. On the off chance that it were not for GurusadayDutt, whose assortment of taps turned into a piece of his Bengali people craftsmanship historical center, and to a lesser part current craftsman, Jamini Roy, they may have been overlooked altogether in the urban cognizance. Then, Mohandas Gandhi and Rabindrinath Tagore were wholeheartedly advancing the notoriety of customary Indian art craftsmanship to the whole populace of India. Here and there it is a gift that patachitra was kept separate from the pre-Independence workmanship development.

\section{Understanding the Background}

Large scale manufacturing and advertising of people makes weakened the conventions whereupon they were based. I have been contending that adjustment is fundamental, however when people craftsmanship dismisses its starting points completely it dangers getting simply business. People craftsmanship at its center is comprised of two 
components, down to earth use and tasteful custom, which suggests a more profound significance to the network wherein it exists. Lose either altogether and the fine art is deprived of its verifiable respectability. On account of Kalighat painting patachitra changed to reflect another general public, without losing its uniqueness, holding tight to the hilarious society maxims and social qualities it previously had. A parity must be struck among adjustment and staying consistent with priority. Similar individuals who were fighting for Indian autonomy financially were incidentally taking a chance with the loss of their social uniqueness by utilizing a Western creation model to support the separate Indian specialty advertise.

\section{Role of Tagore \&Shantinikaten}

In 1921, Tagore, effectively an observed Bengali author, established a college in Shantiniketan, a littler city north of Calcutta, which he called Visva-Bharati, or "a world college." Rebecca M. Earthy colored composes that Visva-Bharati "had as its center undertaking the advancement of abstract and masterful feel interfacing with India's past and people legacy."

Tagore was stressed over the loss of recorded point of view in Indian colleges to British influence. In the mid nineteenth century, the top Indian craftsmen were prepared at territorial schools built up in significant urban areas: the Bombay School, the Calcutta School, the Madras School. The styles educated at these schools depended on the standard of straight viewpoint and authenticity imported from the British Royal Academy.

Visva-Bharti contained inside it a school of fine expressions, the Kala Bhavana, which was the brainchild of Tagore and the school's executive, Nandalal Bose. Their goal was to break up the obstruction among expert and fine craftsman, imparting in their understudies an energy about India's creative legacy. ! ! Be that as it may, the objective of craftsmen joined through patriot pride, paying little heed to class foundation, was not to be. Rather the partition between the upper and lower class craftsmen turned out to be significantly more prominent, with each side dismissing one piece of the establishments of the people workmanship convention that was at the core of Tagore's aims, either its stylish legacy or its useful use. SilpaBhavana, another school inside the college, was begun by Tagore and his little girl inlaw in 1922 for preparing country grown-ups and youngsters in specialties and businesses for proficient advancement purposes. These individuals were not from innate craftsman families and must be prepared starting from the earliest stage.

Thus, the items that they made were intended to satisfy the upper and white collar class stylish taste, the new market to whom people workmanship could be sold as help for a national reason, a substitute for imported merchandise. As indicated by K.G. Subramanyan, a professor of painting at Kala Bhavana, "the particular 'Craftsmanship Nouveau' flavor perceivable in the feel of the Tagores accommodating East with West, workmanship with make, individual imagination with large scale manufacturing... saturated the SilpaBhavana items... and struck a thoughtful harmony in the sensibilities of the developed world class of that time." along these lines Tagore's endeavors sold out the credibility of the craftsmanship, with their fashioners forming the items to fit a urban perfect rather than the catalyst originating from conventional society craftsmen themselves. SilpaBhavana items pandered to the flavors of Indian urbanites losing its customary style. In the interim on the Kala Bhavana end, upper and working class craftsmen were holding the stylish however losing the history behind it. As a proceeded with disobedience to exacting European work of art, youthful specialists in India, much the same as youthful craftsmen in Europe, were searching for another "crude" stylish for motivation. Be that as it may, where Picasso and his colleagues discovered African covers, Indians started to reveal their own foundations. This is the thing that basically isolates Indian innovation from its European partner. Rather than 
responding to the famous "other," they were thinking back in on themselves.

Subramanyan condemns these early Visva-Bharati understudies for utilizing people expressions shallowly, for their tasteful excellence just, missing the useful application component thatis at the core of society. This pattern stretched out past the college and turned into a well known path for present day Indian craftsmen to get to the "crude". It is imperative to comprehend the monetary benefit that they held in this circumstance. Jamini Roy, one of the most observed Modern painters in India, is a prime case of a urban craftsman who had the option to utilize society figures of speech for his own creative vision. Prepared in European artistic creation in Calcutta in the late nineteenth century, he got exhausted with his work until he found Kalighat painting during the 1930s and utilized it as motivation for a portion of his most praised artworks of subjects from both Christian and Hindu folklore. Be that as it may, once more, his work has been censured for not having enough society establishing past stylish intrigue. Subramanyan portrays Roy's Kalighat style artworks as being "without the naturalness and verve or the guileful cleverness of its nearby people models."

This is the monetary world into which Bengali patachitra made its return during the 1970s. At the point when consideration was finally paid to the society painters of West Bengal once more, their specialty was in an inauspicious decrease. Ruby Palchoudhuri, one of the establishing individuals from the Crafts Council of West Bengal, took patuas, or possibly individuals from families that truly created patachitra, to the GurusadayDutt Museum in Calcutta, demonstrating them the work that their progenitors had done, which none of them knew about. Their absence of information about their own history was not abnormal given the conditions. With the influx of TV and motion pictures into provincial life, less and less individuals needed to watch patuas performing stories from the Hindu legends.

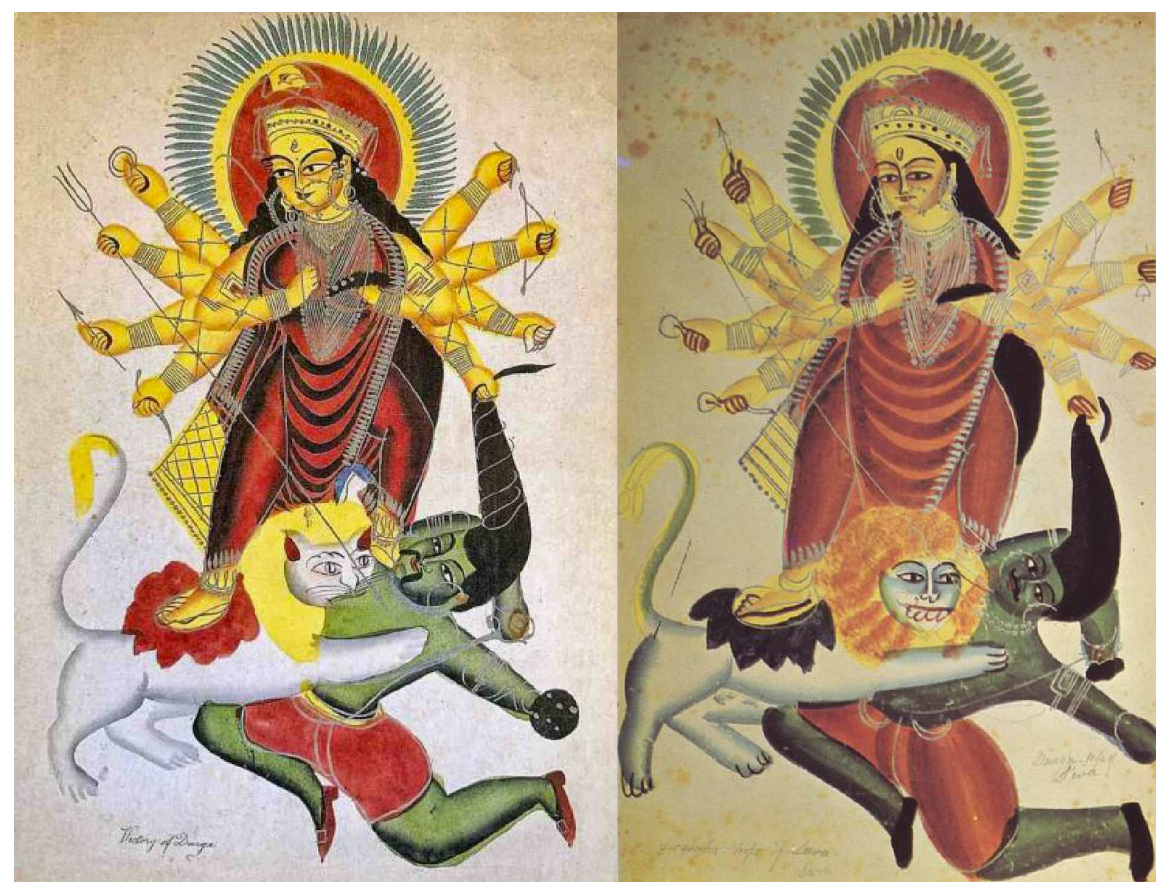




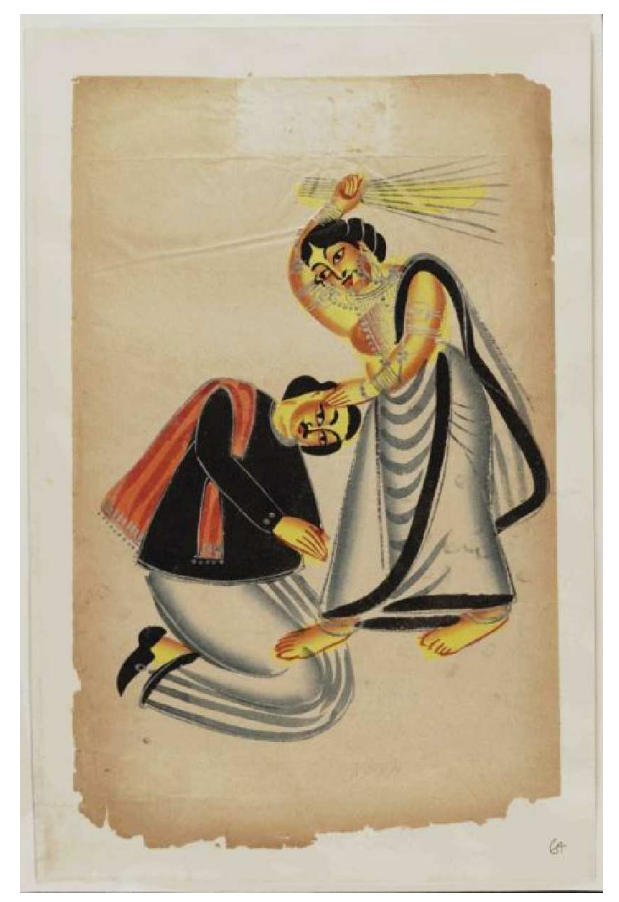

Retrieved on May 16th 2020 from https://theculturetrip.com/asia/india/articles/a-brief-history-ofkalighatpaintings-in-kolkata-india/

Numerous families had surrendered their specialty to move to increasingly profitable callings. Others had quit showing their kids the training regardless of whether they proceeded with it themselves. This raises the third essential component to the gift of society craftsmanship: usually a specialty is the main occupation that a craftsman has, it is win or bust. Obviously it was the ideal opportunity for patachitra to make another versatile move to get by, with the danger of making a trip not far off to commercialization, as other people expressions before it. 


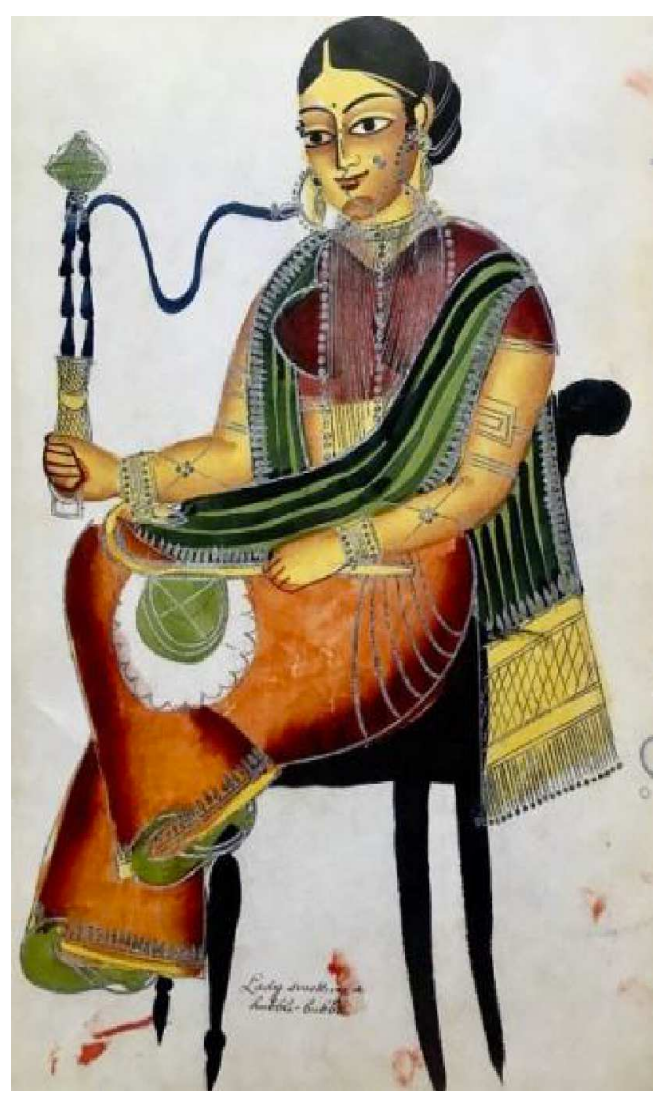

Retrieved on May 16th 2020 from https://theculturetrip.com/asia/india/articles/a-brief-history-ofkalighat-paintings-inkolkata-india/

\section{CONCLUSIONS}

Visual culture is probably the most straightforward approaches to recognize one gathering of individuals from another. People craftsmanship is a term utilized essentially to depict hand created workmanship that includes some reasonable capacity inside a network. It gives a vocation to its specialists that have been passed down for ages, connected together by a tasteful convention, and can along these lines be viewed as an agent part of a given culture. In India, the networks related with society craftsmanship are essentially rustic, and hence have less access to the innovations and media which have radically modernized the lives of urban residents. As a result of the more slow movement of globalization in country life, the craft of provincial networks is much of the time viewed as a kind of constant social time case, a lingering home for social uniqueness to mitigate the nervousness created by losing social legacy in globalized urban focuses. Patachitra, in its numerous structures, demonstrates that the best trust in society craftsmanship is safeguarding through adjustment. In the midnineteenth century, close to the beginnings of what we call globalization today, Calcutta, presently Kolkata, the capital of West Bengal, turned into a focal goal for outsiders looking for monetary chances, numerous patuas among them. The introduction of Kalighat painting, an adjusted form of patachitra, which advanced as a culture of cosmopolitanism developed in Calcutta, was a characteristic improvement as the craftsmen responded to the new estimations of their general public. Legendary HistorianJyotindra Jain qualified the Kalighatpatuas as, "the first Moderns," for the exceptional manner by which their work reacted to the new.

\section{REFERENCES}

1. Jyotindra Jain, “Kalighat Painting: Images from a Changing World”, Mapin Publishing Pvt. Ltd., Ahmedabad 1999 
2. S Chakravarti (ed.) “Kalighat Paintings in Gurusaday Museum”, GurusadayDutt Folk art Society, Kolkata 2001

3. MukulDey, “The Painters of Kalighat: 19th Century Relics of a Once Flourishing Indian Folk Art Industry Killed by Western Mass Production Methods", The Statesman, Calcutta, Sunday, October 22, 1933 (Courtesy: http://www.chitralekha.org/articles/mukul-dey/painters-kalighat-19th-centuryrelicsonce-flourishing-indian-folk-art-industryk)

4. https://www.penn.museum/documents/publications/expedition/PDFs/42-3/Kalighat.pdf

5. Tahmina, S., \& Al Mahmud, M. U. H. A. M. M. A. D. Indian Sub-Continental Nationalist And Japans Role For The Emergence Of Bengali Nationalism.

6. Bhola, M. Gandhian Thought and Nationalism in Waiting for the Mahatma.

7. Sodhi, S., Arya, N., \&Yadav, N. Assessment of Adapted Motifs of Madhubani Painting. 